\title{
Publication Bans in a Facebook Age: How Internet Vigilantes Have Challenged the Youth Criminal Justice Act's "Secrecy Laws" Following the 2011 Vancouver Stanley Cup Riot
}

\author{
Tania Arvanitidis \\ Simon Fraser University
}

On June $15^{\text {th }}$, 2011, a hockey riot occurred in Vancouver, British Columbia. This event is prominent in Canada's history for, among other reasons, the unprecedented extent to which it was documented via photographs and video footage. The days that followed the riot saw much of this media documentation uploaded to social media platforms on the Internet, where Internet users worked together to identify and collectively "name and shame" those believed to have been involved in the disturbance. Several individuals targeted by these "Internet vigilantes" were young offenders whose identities are legally protected from publication under the Youth Criminal Justice Act (YCJA). This article examines the phenomenon of "Internet vigilantism", and raises the issue of whether those provisions within the YCJA that prohibit the identification of youth remain relevant today, given the current difficulties in enforcing these provisions. Following an overview of these "secrecy provisions", the phenomenon of Internet vigilantism is defined, and challenges posed by acts of Internet vigilantism are discussed. A "naming and shaming" Facebook group created for the purpose of identifying participants in the 2011 Vancouver riot is then looked to as a case study of Internet vigilantism in action. This article concludes with recommendations for how justice officials and social media outlets may modify current practices to better protect the safety and security of young offenders, and to minimize harmful instances of Internet vigilantism.

Keywords: Young offenders; Riots; Cyber-Vigilantism; Facebook

Le 15 juin 2011, une émeute liée au hockey s'est déroulée à Vancouver, en Colombie-Britannique. Cet événement est important dans l'histoire du Canada, entre autres raisons, pour sa documentation sans précédent par l'entremise de photographies et de séquences vidéos. Les jours qui ont suivi l'émeute, une grande quantité d'information médiatique a été téléchargée sur les médias sociaux, où des internautes collaboraient afin d'identifier et de «nommer et pointer du doigt » ces personnes qui auraient participé aux troubles sociaux. Plusieurs individus ciblés par ces « justiciers de l'Internet » étaient de jeunes contrevenants dont l'identité est légalement protégée contre la publication en vertu de la Loi sur le système de justice pénale pour les adolescents (LSJPA). Cet article se penche sur le phénomène des « justiciers de l'Internet » et s'interroge sur la pertinence actuelle des dispositions dans le cadre de la LSJPA qui interdisent l'identification des jeunes, étant donné les difficultés présentes à faire respecter ces dispositions. Après un aperçu de ces « dispositions relatives au secret », le phénomène des justiciers de l'Internet est défini, et les défis posés par leurs actions sont discutés. Le groupe Facebook qui visait à « nommer et pointer du doigt » les participants de l'émeute de 2011 de Vancouver est présenté ici comme une étude de cas sur les justiciers de l'Internet. Cet article formule des recommandations sur la façon dont les fonctionnaires de la justice et les médias sociaux peuvent modifier les pratiques courantes afin de mieux protéger la sécurité des jeunes délinquants et réduire au minimum les effets nuisibles découlant des actions des justiciers de l'Internet.

Mots-clés: jeunes contrevenants; émeutes; cyber-justiciers; Facebook 


\section{Introduction}

On June 15th 2011, British Columbia's National Hockey League Team, the Vancouver Canucks, played their seventh and final game of the Stanley Cup Finals against the Boston Bruins. The Canucks' loss against the Bruins was followed by one of the most destructive and memorable riots in the city's history. Of the thousands of photographs taken by bystanders that night, one of the most iconic remains that of Nathan Kotylak, a 17-year-old former star athlete, seemingly attempting to light a police car on fire. The photograph was published online almost immediately following the riot, where it was shared innumerable times on various Internet social media sites. Within hours, Kotylak was identified by users on the social media website Facebook (Schneider \& Trottier, 2012). The backlash he suffered from the public shortly after was immediate, merciless, and overwhelmingly public. As the photograph continued to make its way across the Internet, Kotylak found himself subjected to a torrent of verbal abuse, demands for punishment, and threats, until eventually he and his family were forced to flee their home following the publication of their home address online (Ryan, 2012). To this day, an Internet search of Kotylak's full name yields pages upon pages of news articles and blog posts devoted to vilifying him.

The unrelenting "naming and shaming" that Nathan Kotylak was subjected to following the 2011 Vancouver riot exemplifies a relatively recent and little understood phenomenon that has been described as "cyber vigilantism", "digitalism", or more commonly, "Internet vigilantism" (Juliano, 2011; Wehmhoener, 2010). Internet vigilantism raises a number of concerns pertaining to the overlapping realms of privacy, free speech, and criminal law - and online "naming and shaming", in particular, raises concerns regarding the enforceability of provisions within the Youth Criminal Justice Act that intend to prevent the publication of young offenders' names in any sort of public media. Though the consequences of violating a publication ban mandated by the Act are serious, these provisions are gradually becoming more difficult to enforce, as the Internet increasingly enables users to easily sidestep these laws.

Nathan Kotylak's experience does not signify the first instance in which young offenders have been identified online and made targets for subsequent public naming and shaming. Almost four years earlier, on January 1 2008, 14-year-old Stefanie Rengel was murdered by David Bagshaw in Toronto, Ontario, after being stabbed repeatedly in the stomach on the sidewalk near her home. The murder was reportedly orchestrated by Bagshaw's girlfriend, 15-year-old Melissa Todorovic, who had pressured Bagshaw into committing the murder when she began to see Rengel as a rival and grew jealous (Jones, 2013). Rengel was a popular and well-liked student at her school, and despite strong efforts on the part of justice officials and police to protect both her identity and the identities of the accused, a Facebook group was soon established for the purpose of mourning her death. Many angry and frustrated Facebook users posted to the group with the intention of publicizing the identities of Bagshaw and Todorovic; others did so imploring that they be tried as adults for the murder (Pallanik, 2008).

This case is merely one of many that, in recent years, have brought to the attention of justice officials the numerous difficulties involved in protecting the identities of young offenders on the Internet. The unprecedented magnitude of the Internet vigilantism that followed the 2011 Vancouver riot, in particular, urges us to reassess how secrecy provisions for young offenders can be enforced in a "Facebook age" - if, indeed, they can be enforced at all. This short paper addresses the phenomenon of Internet vigilantism and the problems it poses for the safety and privacy of those targeted by it, particularly when those targeted are young offenders whose identities are legally protected from publication. I begin with an overview of those provisions contained within 
the Youth Criminal Justice Act that prohibit the publication of young offenders' names in all but exceptional circumstances, then turn to an exploration of the motivating factors behind Internet vigilantism. Next follows a discussion of the Internet vigilantism that followed the 2011 Vancouver riot, and a brief examination of the posts made to a particularly popular "naming and shaming" Facebook group created soon after the event. Based on the content of these posts, preliminary recommendations are offered for how both justice officials and social media websites may modify current practices and policies to better protect the safety and privacy of sensitive individuals, including youth.

\section{The Youth Criminal Justice Act and the Logic of Publication Bans}

The Youth Criminal Justice Act (hereby referred to as the YCJA) is the law that governs Canada's youth justice system. It replaced the Young Offenders Act when it came into effect on April 12003 , and covers the prosecution of youths at least 12 years of age but under 18 years old for criminal offences. One of the many ways in which the YCJA is distinguished from the Young Offenders Act - and its predecessor, the Juvenile Delinquents Act - is through its prohibition of the publication of information that would identify youth accused of committing criminal acts, as well as youth who have been victims of crime (Department of Justice Canada, 2013b). The provisions outlining how and when this general publication ban is to be enforced are contained within s. 110 and s. 111 of the YCJA:

110. (1) Subject to this section, no person shall publish the name of a young person, or any other information related to a young person, if it would identify the young person as a young person dealt with under this Act.

$[\ldots]$

111. (1) Subject to this section, no person shall publish the name of a child or young person, or any other information related to a child or a young person, if it would identify the child or young person as having been a victim of, or as having appeared as a witness in connection with, an offence committed or alleged to have been committed by a young person.

This publication ban is justified on the basis that publicizing information pertaining to the identity of a young offender has the potential to be so stigmatizing and harmful in its consequences that it can hinder the youth's eventual rehabilitation. This logic is in accordance with the YCJA's Declaration of Principle (contained within s. 3), which states that a primary goal of Canada's juvenile justice system must be, above all else, the reintegration of young offenders into society through rehabilitative and preventative channels wherever possible. This, in turn, is based on the premise that youth are more immature than adults, and thus typically possess greater outlooks for rehabilitation; it is this same logic that also informs the fundamental need for juvenile justice legislation separate from that of adults. Barring a number of exceptional circumstances under which such a ban may be lifted, breaking a publication ban imposed on a young person is a serious criminal offence. The publication of information which may reveal the identity of a young person, victim, or witness can carry a penalty of up to two years in custody (Department of Justice Canada, 2013b).

Within the YCJA, publication is defined as the communication of information by making it known or accessible to the general public "by any means" - including through print, radio, television or other electronic medium. Although it is not explicitly stated, s. 110 and s. 111 of the 
YCJA are typically interpreted to include within the scope of "publications" the posting of identifying information on social media outlets, in accordance with the Act's intentions (Department of Justice Canada, 2013a). However, the legal issues that surround these interpretations remain highly complicated, which subsequently limits their enforceability (Powell $\&$ Mitchell, 2008). There is still no consensus, for example, as to whether all user pages created on the social media website "Facebook" are to be treated as "publications", since the website grants users a large amount of control over the individual privacy settings of all posted content. Additionally, whether or not individual Facebook pages are indexed by search engines such as Google is also contingent on users' self-established privacy levels, which can be set to limit search engines' access. A further concern that has yet to be resolved is the fact that Facebook is an American site outside of Canadian legal jurisdiction, raising jurisdictional questions pertaining to whether, and when, Canadian publication bans against naming young offenders and victims would even apply (Millar, 2008). These numerous difficulties in policing the domain of the Internet have led to a number of public discussions as to whether the YCJA's "secrecy provisions" still have relevance today (see Millar, 2008; Powell \& Mitchell, 2008; Shanoff, 2011).

\section{Naming, Shaming, and Internet Vigilantism}

"Vigilante justice" describes the undertaking of any number of acts of law enforcement without legal authority. Though vigilantism is a well-documented and recognizable phenomenon, definitions and conceptualizations as to exactly what kinds of acts constitute vigilante justice are varied (Juliano, 2011; Wehmhoener, 2010). Johnston's (1996, p. 220) highly versatile definition is employed for this paper, which identifies acts of vigilantism according to six key characteristics:

1. It involves planning and premeditation by those engaging in it;

2. Its participants are private citizens whose engagement is voluntary;

3. It is a form of autonomous citizenship and as such, constitutes a social movement;

4. It uses or threatens the use of force;

5. It arises when established order is under threat from the transgression, the potential transgression, or the imputed transgression of institutionalized norms;

6. It aims to control crime or other social infractions by offering assurances (or 'guarantees') of security both to the participants and to others.

"Internet vigilantism" shares many, and often all, of these characteristics, and thus may be defined as vigilante justice that occurs in the domain, or with the aid, of the Internet. There are many different forms which Internet vigilantism may take, but it is "naming and shaming" that arguably raises the most concerns regarding the enforceability of publication bans and the protection of youths' privacy. This term refers to the identification of perceived wrongdoers and, in the absence of traditional means by which to inflict physical harm, the subsequent infliction of shame or harassment upon them (Wehmhoener, 2010).

Arguably all acts of vigilante justice create risks for both justice officials and the general public, and those created by the actions of Internet vigilantes are no different. Because vigilantism is typically engaged in by individuals not affiliated with the formal justice system, punishments may be vastly disproportionate to crimes, acts of vigilantism may interfere with or impede attempts on the part of the formal justice system to bring offenders to justice, and - perhaps of most concern - the wrong individual may be targeted (Huey et al., 2013; Johnston, 1996; Wehmhoener, 2010). Yet vigilantism that takes place on the Internet is arguably even more threatening than other more 
traditional forms of vigilantism, because of how difficult the domain of the Internet is to police. Following Stefanie Rengel's murder, for example, police and Facebook staff made numerous attempts to comply with the YCJA by deleting posts which identified Rengel and/or her killers, but ultimately could not put a permanent stop to the republishing of the deleted information by individual users (Pallanik, 2008).

Much of the difficulty of policing acts of Internet vigilantism stems from the same reasons it holds appeal in the first place: The nature of the Internet allows users to remain anonymous with ease (see Torrevillas, 2011; Wehmhoener, 2010). Several classic studies on the effects of anonymity have found it to play a key role in enabling antinormative and criminal behaviours (Cannavale, Scarr \& Pepitone, 1970; Kiesler, Siegel and McGuire, 1984; Mann, 1981; Mathes and Guest, 1976), as well as in increasing aggression (Donnerstein, Donnerstein, Simon, \& Ditrichs, 1972; Mathes \& Kahn, 1975; Page \& Moss, 1976). These patterns have been observed in recent studies on computer-mediated communication as well: Santana (2014), for example, found that Internet comments posted anonymously were more frequently "uncivil" compared to comments posted nonanonymously, while other studies have identified positive relationships between anonymity and cyberbullying (Barlett; 2013; Moore, Nakano, Enomoto, \& Suda, 2012) and anonymity and "cyber-aggression" (Wright, 2013, 2014; Zimmerman \& Ybarra, 2014), respectively. Consistent with deindividuation theories, these findings suggest that those who engage in Internet vigilantism may often be law-abiding individuals who, with the aid of the Internet, are empowered to behave in ways contrary to that of how they would in the "real world" (see Suler, 2004).

On a much broader societal level, the "naming and shaming" of those who commit crimes is not an unfamiliar justice practice. It is typically justified by supporters on the basis that such tactics not only deter offenders from reoffending, but prevent crime at the general societal level as well through "setting an example" for others (see Golash, 2013). Though the logic of this approach is appealing in its simplicity, it does not appear to translate well into practice: In the United Kingdom, the breach rate for youth who receive Anti-social Behavior Orders (ASBOs) - and, subsequently, have both their orders and identities publicized - is significantly higher than that for adults who receive similar orders (UK Ministry of Justice, as cited in Crofts \& Witzleb, 2013). Additional research suggests that "naming and shaming" tactics that result in stigmatizing labels for offenders can affect future access to conventional opportunities (Bernburg \& Krohn, 2003; De Li, 1999; Lanctôt, Cernkovich, \& Giordano, 2007), as well as increase the likelihood of rejection by conventional peers (Bernberg, Krohn, \& Rivera, 2006). Furlong and Keefe (2011, p. 123), in their comprehensive review of the 2011 Vancouver riot, also acknowledge that practicing "naming and shaming" towards riot participants may punish them to the detriment of their rehabilitation:

Many young people break the law. Not many years ago if a person was not caught by the police, prosecuted, and convicted, there would be no record of it. And, if there was, it would be sealed. Today a young person, perhaps with the help of the stranger cheering his antics, can create his own criminal record - one that cannot be expunged - to dog him for the rest of his life.

Indeed, as increasingly more people share their experiences with having been the targets of online "naming and shaming", the consequences of this practice are revealed as particularly devastating for the "offender" when they occur on the largely-unregulated domain of the Internet ranging from termination from one's job (Koetsier, 2013), to the online publicizing of one's 
personal contact information for harassment purposes (Tan, 2008), to the near-total destruction of one's personal and professional reputation (Ronson, 2015). Based on these accounts, Internet vigilantism, and "naming and shaming" in particular, can be understood as akin to convicting and sentencing an individual to life in a virtual jail - one with no rules, regulations, or protection from abuse.

\section{"Vancouver Riot Pics: Post your Photos": Internet Vigilantism in Action}

The 2011 Vancouver Stanley Cup riot is a unique example of Internet vigilantism in action. What distinguished this riot from other major criminal events in Canada's history - including a hockey riot that took place in downtown Vancouver in 1994, under very similar circumstances (Furlong \& Keefe, 2011) - was how prominently the Internet, and social media in particular, featured in the community's response to the disturbance.

To gather evidence and apprehend those who participated in the riot, an enormous effort was made on the part of the Integrated Riot Investigation Team (IRIT) to secure the cooperation of the public, primarily through encouraging the submission of photographic and video evidence from the night of the riot. In addition to printing out flyers bearing the faces of alleged rioters for the purposes of distributing to the public, a website was set up immediately following the riot to allow those with evidence to upload it directly to police. This highly novel evidence-gathering strategy has been described by Schneider and Trottier (2012) as "crowdsourced policing". Coined by Jeff Howe (2008, as cited in Schneider \& Trottier, 2012), "crowdsourcing" is a term now typically used to refer to the practice of obtaining needed services, ideas, or content by soliciting contributions from a large group of people (most typically, an online community); "crowdsourced policing" may thus describe the soliciting of "pseudo-police work" from individuals not affiliated with law enforcement. This tactic proved extremely advantageous to the IRIT's investigation: By October 31 2011, the IRIT had managed to process "over 30 terabytes of data" and "over 5,000 hours of video" (Schneider \& Trottier, 2013), with so much evidence sent to police on June 162011 - the day following the riot - that the website temporarily crashed (Vancouver Police Department, 2011).

As these investigative efforts on the part of the IRIT took place, citizen-led efforts to "crowdsource" justice began to spring up simultaneously on a number of social media platforms. In the mere hours that followed the riot, public Facebook groups with names such as "[the] Vancouver Riot Wall of Shame", "Vancouver Riot Pics: Post Your Photos", and "Report Canuck RIOT Morons" were set up to enable and encourage those present at the riot to upload photographs, videos, and any other evidence incriminating to alleged rioters (Arvanitidis, 2013; Robinson, Kane, Duggan, \& Law, 2011). Consistent with the IRIT's goals, the stated intent of these groups was to expose rioters in a public venue in order to coerce them to turn themselves in (and, later, to assist the IRIT in their investigative efforts). Yet almost immediately, many who joined the groups took to using their public nature to simply "name and shame" alleged rioters through insults, humiliating remarks, and even threats. In some instances, acts of "naming and shaming" escalated to the point that highly personal information pertaining to alleged rioters, such as phone numbers, home addresses, and the names of family members, were published online, leading to some suspects including Nathan Kotylak - being personally harassed and threatened by strangers (Finch, McIntyre, \& Sundberg, 2012; Robinson et al., 2011).

"Crowdsourced policing", as described above, is not an entirely novel approach to crime control. The distribution of "wanted" posters, for example, illustrates an early version of this tactic; the practice is also seen in myriad crime-based reality shows that encourage audiences to submit 
information that could lead to the prosecution of criminal suspects (Cavender \& Bond-Maupin 1993; Fishman \& Cavender 1998). However, the widespread availability of portable devices capable of capturing photo and video, coupled with the sudden popularity of social media technologies and culture, have revolutionized the ease with which police evidence-gathering work may be "crowdsourced" today (Powell \& Mitchell, 2008; Robinson et al., 2011). The fundamental structure of social media platforms such as Facebook, Tumblr, and Twitter enable users to document and disseminate information about global events with unprecedented ease and speed. User accounts on these sites are enormous repositories of potentially incriminating information, and the semi-public nature of these platforms allow for the relatively easy publication of said information - including by accident - from an individual profile to a public group. The dissemination of users' personal information is further enabled by the networked structure of these sites, which easily allows users to both access others' personal information, and distribute that information to a large number of individuals. Even further, users do not need to follow any particular criminal justice protocol in order to distribute information, thus allowing incriminating information to be shared almost immediately; in fact, many individuals who took part in the riot were being identified and shamed online even while the riot was still taking place (Schneider \& Trottier, 2012, 2013).

Schneider and Trottier's $(2012,2013)$ qualitative examinations of user responses to the 2011 Vancouver riot on the social media website Facebook have shed valuable insight into how individuals made sense of the riot in the days that followed, and justified their own acts of Internet vigilantism. Their research focused on, arguably, the largest and most popular Facebook group for posting photos and video evidence incriminating to rioters following the riot: A group named "Vancouver Riot Pics: Post Your Photos". 12,587 user postings were made to the group's primary wall in just 14 days following the riot, and the page received more than 70,000 "likes" in less than 24 hours (Schneider \& Trottier, 2012, 2013). Their findings, summarized briefly in the following sections, point to a number of motives underlying how and why individuals were motivated to engage in Internet vigilantism following the 2011 Vancouver riot, and provide guidance as to what steps may be taken to reduce instances of Internet vigilantism that threaten the safety and security of young offenders.

\section{Perception of Riot Participants as Inherently Deserving of Stigmatization}

Many of the hostile comments made by users to the group page stemmed from desires to denounce and ostracize those who participated in the riot, as well as to distance themselves from participants. The riot was largely blamed on the actions of "idiots" and "morons" who were not "true" hockey fans or Vancouverites, and suggestions were made that the rest of "us" (i.e., law-abiding responsible citizens of Vancouver and the world) should bring them to justice. Many of these comments echoed those made by Chief Constable Chief Chu of the VPD who, in the days following the riot, claimed that those instigators among the mob were "criminals, anarchists, and thugs' (Cole, 2011). Although it has since been demonstrated that the vast majority of participants in the riot were first-time offenders (Arvanitidis, 2013), the construct of the rioters as "morons" and "bad apples", fundamentally distinct from the good law-abiding citizens of Vancouver, appeared to have already become established in the mentality of those who created and drove the Facebook group. 


\section{Perception of Riot Participants as Responsible for Own Online Stigmatization}

Many alleged rioters who were "named and shamed" within the group were blamed for their own ignorance of being filmed and photographed. These sentiments are indicative of not just attitudes towards those who participated in the riot, but of significant overall shifts in the degree to which social media users now perceive themselves to be at constant risk of being surveyed and reported to authorities by others. Consistent with this findings, a recent study on social media and visibility found that many respondents adopted several strategies to managing their social media profiles in order to avoid information leaks, ranging from limiting access to their information through tight privacy settings to self-censorship; they subsequently assumed that avoiding criminal charges was as simple as not "doing something stupid" (Trottier, 2012).

\section{Perception of Vigilantism as Providing Assistance to Justice Officials}

A number of user posts appeared to communicate the belief that "naming and shaming" alleged rioters was not only in line with the criminal justice system - that is, that doing so did not violate any existing laws prohibiting libel, threats, or harassment - but that such efforts actively assisted with the prosecution of rioters and the efforts of the IRIT. The VPD e-mail address was found to have been posted in the group over 140 times for users to forward pictures, videos, and names to, and several users outright claimed that police were actively asking people to join the group and "tag" individuals - that is, assign a name to a photograph of a person - if they recognized them (this claim that has never been verified). Still other user posts did not communicate a specific intent to assist in law enforcement efforts but nonetheless expressed a desire to see "punishment" and/or "justice" meted out to riot participants, suggesting that at least some of these individuals may have understood, on some level, that their acts of "naming and shaming" would have implications for the identification and apprehension of riot participants.

\section{Perception of Group as Necessary to Circumvent Formal Justice System}

In addition to those users who uploaded photos to the Facebook group in order to assist police in their prosecution efforts, some users who submitted evidence were motivated by a desire to circumvent the state-sanctioned justice system altogether. These individuals typically expressed dissatisfaction with the criminal justice system, particularly for delays in prosecuting those responsible for the riot, but also for its perceived leniency. Some expressed particular dissatisfaction with the differential treatment that young offenders receive in the Canadian criminal justice system - and, in particular, perceived the YCJA as overly lenient and ineffective at punishing young offenders. It was also found that a number of users directly referred to both their actions, and the actions of others, as "vigilantism" (Schneider \& Trottier, 2013, p. 353) - suggesting that for at least some of these users, participation in this group constituted a deliberate attempt to circumvent the criminal justice system in order to deliver, instead, a civilian-led form of justice. This finding is also consistent with the knowledge that vigilantes often justify their actions on the grounds that adequate legal mechanisms for criminal punishment are, in the given situation, either nonexistent or insufficient (see Johnston, 1996; Juliano, 2011; Wehmhoener, 2010). 


\section{Discussion and Recommendations}

The 2011 Vancouver riot saw social media and crowdsourced policing take "naming and shaming" to an unprecedented level that proved particularly threatening to the protection of young offenders' identities. There is no question that the YCJA's emphasis on the rehabilitation and reintegration of young offenders retains merit to this day; however, the myriad difficulties that social media creates in enforcing these provisions raise urgent questions regarding their applicability in this day and age, at least in their current form. Policing agencies typically lack the resources to effectively deal with cybercrime (Huey et al., 2013), and the long and complicated procedural process that awaits changes to the YCJA cannot keep up with the rapid pace at which social media technology evolves and changes. Innovative collaborative efforts, within and across various public and private sectors, may thus be the only feasible way to enforce the YCJA's secrecy provisions today. From what is presently understood about why social media users "named and shamed" rioters following the 2011 Vancouver riot, a number of alternative recommendations follow for how similar instances of "naming and shaming" may be minimized in the future.

Social media platforms can inform users of the legal ramifications of their actions. As indicated by the belief that their actions were assisting police, many social media users who engaged in acts of vigilantism following the Vancouver riot may have been unaware that their actions were breaking any existing Canadian laws; indeed, it is likely that many Facebook users do not know enough about Canadian Law to even be aware of when they are breaking it, on account that many are young people themselves (Millar, 2008). Little effort has been devoted towards educating the general public about important Criminal Code and YCJA provisions, and social media platforms such as Facebook have made no significant effort to inform users of the legal ramifications of their actions. It would be beneficial for social media platforms to require users to familiarize themselves with the potential risks and harms associated with the publication and sharing of different kinds of information.

Social media platforms can introduce mechanisms that discourage acts of "naming and shaming". For example, if anonymity is assumed to be a key factor in enabling "naming and shaming" behaviours, then putting in place mechanisms which limit the extent to which social media users are able to post anonymously may see a decrease in this form of Internet vigilantism. American multinational corporation Google, for example, recently revamped the comments function on video-sharing website YouTube so that users now cannot comment unless they link their Google+ accounts, which require user profiles to correspond with users' first and last names (Misener, 2013). It must be noted that these "real name" policies have not gone without criticism, with many noting that they are unaccommodating and discriminatory towards social media users who do not wish to reveal their legal identities online due to safety concerns (Holpuch, 2015); an alternate prevention strategy may thus be to simply increase the severity of penalties associated with online "naming and shaming" practices. Social media website reddit.com, for instance, recently had its policy updated to prohibit acts of harassment and "doxxing" (the publication of non-public personally-identifying information pertaining to an individual or individuals), under threat of being permanently banned from the website (Ore, 2015).

Police can limit their reliance upon evidence-gathering strategies that encourage Internet vigilantism. Although the IRIT was not directly responsible for the actions of the Internet vigilantes who assisted them, Schneider and Trottier's (2013) analysis suggest that the IRIT's repeated requests for assistance from the public may have contributed to the fervor with which citizens then jumped to the opportunity to "name and shame" suspected rioters. It may thus be argued that justice 
officials have a social responsibility to consider how untested tactics like "crowdsourced policing" may incite citizen-led acts of vigilantism. The finding that many social users believed they were supported in their efforts to mete out justice suggests an additional responsibility on the part of justice officials to inform would-be vigilantes of exactly what actions encompass "vigilantism", particularly in the online realm; a brief statement on the Vancouver Police Department's Riot 2011 website $^{1}$ asked only that citizens "resist the temptation to take justice into their own hands", without specifying details as to what doing so would entail.

Journalists can be attentive of language that supports "naming and shaming". In the days that followed the 2011 Vancouver riot, news stories and editorials discussing the event were heavy with emotional language indicative of shame, anger, and embarrassment - all consistent with the shaming language observed within posts made to the "Vancouver Riot Pics: Post Your Photos" Facebook group (see Arvanitidis, 2013). This parallel is of note because the language used to describe criminal events, and criminal actors, has been found to have implications for how readers then come to understand these events: Specifically, the use of biased, negative language to describe criminal actors may be seen as informative of their inherent character traits, in line with the fundamental attribution error (see Dripps, 2003; Neapolitan, 1987). This begs the important question of whether these initial news reports lent legitimacy to the shaming practices that eventually gained traction within the "Vancouver Riot Pics" Facebook group.

The 2011 Vancouver riot serves as a valuable case study in both the merits, and dangers, of what happens when social media users come to the aid of law enforcement officials. According to the Vancouver Police Department's (2011) official Riot Review, the substantial number of arrests that police were able to make in the weeks following the riot was directly impacted by their efforts to "crowdsource" evidence, demonstrating that the general public can indeed be a significant partner to police agencies. The question that remains to be answered in this paper is whether these benefits outweigh the potentially devastating consequences of "naming and shaming" that young offenders may find themselves facing with much greater frequency, should such practices come to find mainstream acceptance. A criminal justice system that claims to value the rehabilitative potential of young people cannot, in good conscience, answer "yes" to this question. Without a clear answer as to whether the YCJA's secrecy provisions are relevant today, what must not be forgotten by researchers and policy-makers alike is that vigilantism arises, first and foremost, from a perceived need for justice - the perception that the criminal justice system is not working (Juliano, 2011). If current legal insufficiencies cannot stop social media users from taking the law into their own hands, our only alternative is to continue to increase our understanding of why individuals break laws prohibiting publication bans in the first place, and locate innovative substitutions along the way.

\section{About the author}

Tania Arvanitidis is a Ph.D. student in the department of Criminology at Simon Fraser University. She can be reached at tarvanit@sfu.ca

\footnotetext{
${ }^{1}$ http://vancouver.ca/police/2011riot/
} 


\section{References}

Arvanitidis, T. (2013). From Revenge to Restoration: Evaluating General Deterrence as a Primary Sentencing Purpose for Rioters in Vancouver, British Columbia. (Master's thesis). Retrieved from http://summit.sfu.ca

Barlett, C. P. (2013). Anonymously Hurting Others Online: The Effect of Anonymity on Cyberbullying Frequency. Psychology of Popular Media Culture, 4(2), 7079. doi:10.1037/a0034335

Barlett, C. P., Gentile, D. A., \& Chew, C. (2014, August 18). Predicting Cyberbullying From Anonymity. Psychology of Popular Media Culture. Advance online publication. doi:10.1037/ppm0000055

Bernburg, J. G. \& Krohn, M. D. (2003). Labeling, Life Chances, and Adult Crime: The Direct and Indirect Effects of Official Intervention in Adolescence on Crime in Early Adulthood. Criminology, 41(4), 1287-1317. doi:10.1111/j.1745-9125.2003.tb01020.x

Bernburg, J. G., Krohn, M. D., \& Rivera, C. J. (2006). Official Labeling, Criminal Embeddedness, and Subsequent Delinquency: A Longitudinal Test of Labelling Theory. Journal of Research in Crime and Delinquency, 43(1), 67-88. doi:10.1177/0022427805280068

Cannavale, F. J., Scarr, H. A., \& Pepitone A. (1970). Deindividuation in the Small Group: Further Evidence. Journal of Personality and Social Psychology, 16(1), 141-147. doi:10.1037/h0029837

Cavender, G., \& Bond-Maupin, L. (1993). Fear and Loathing on Reality Television: An Analysis of America's Most Wanted and Unsolved Mysteries. Sociological Inquiry, 63(3), 305-17. doi:10.1111/j.1475-682X.1993.tb00311.x

Cole, Y. (2011, June 16). Police Chief Jim Chu Blames Vancouver Riot on "Criminals, Anarchists and Thugs". The Georgia Straight. Retrieved from http://www.straight.com/article-399630/vancouver/police-chief-jim-chu-blamesvancouver-riot-criminals-anarchists-and-thugs

Crofts, T., \& Witzleb, N. (2013). "Naming and Shaming” in Western Australia: Prohibited Behaviour Orders, Publicity and the Decline of Youth Anonymity (Legal Studies Research Paper No. 13/57). Sydney: Sydney Law School.

De Li, S. (1999). Legal Sanctions and Youths' Status Achievement: A Longitudinal Study. Justice Quarterly, 16(2), 377-401. doi:10.1080/07418829900094181

Department of Justice Canada. (2013a). Publication Bans. Retrieved from http://www.justice.gc.ca/eng/cj-ip/yj-ji/ycja-lsjpa/sheets-feuillets/publi-publi.html 
Department of Justice Canada. (2013b). The Youth Criminal Justice Act: Summary and Background. Retrieved from http://www.justice.gc.ca/eng/cj-jp/yj-jj/ycja-lsjpa/back$\underline{\text { hist.html }}$

Dripps, D. A. (2003). Fundamental Attribution Error: Criminal Justice and the Social Psychology of Blame. Vanderblit Law Review, 56(5), 1385-1438.

Donnerstein, E., Donnerstein, M., Simon, S., \& Ditrichs, R. (1972). Variables in Interracial Aggression: Anonymity, Expected Retaliation, and a Riot. Journal of Personality and Social Psychology, 24(3), 365. doi:10.1037/h0032597

Finch, D., McIntyre, S., \& Sundberg, K. (2012). The Vancouver Riot Hangover: Crowdsourced Justice and Public Shaming. The Centennial Reader (Summer Issue). Retrieved from http://centennialreader.ca/shaming-and-crowdsourcing

Fishman, M., \& Cavender, G. (Eds.) (1998). Entertaining Crime: Television Reality Programs. New York: Aldine De Gruyter.

Furlong, J. \& Keefe, D. J. (2011). The Night the City Became a Stadium: Independent Review of the 2011 Vancouver Stanley Cup Playoffs Riot. Vancouver, BC: Government of British Columbia.

Golash, D. (2005). The Case Against Punishment: Retribution, Crime Prevention, and the Law. New York: New York University Press.

Holpuch (2015, December 15). Facebook Adjusts Controversial 'Real Name' Policy in Wake of Criticism. The Guardian. Retrieved from https://www.theguardian.com/usnews/2015/dec/15/facebook-change-controversial-real-name-policy

Huey, L., Nhan, J., \& Broll, R. (2013). 'Uppity Civilians' and 'Cyber-Vigilantes': The Role of the General Public in Policing Cyber-Crime. Criminology \& Criminal Justice, 13(1), 8197. doi:10.1177/1748895812448086

Johnston, L. (1996). What is Vigilantism? British Journal of Criminology, 36(2), 220-236.

Jones, A. (2013). Melissa Todorovic Appeal: Mastermind In Stefanie Rengel Murder Aims To Overturn Conviction. The Huffington Post (Canada). Retrieved from http://www.huffingtonpost.ca/2013/11/27/ melissa-todorovic-stefanierengel_n_4347926.html

Juliano, S. (2011). Superheroes, Bandits, and Cyber-nerds: Exploring the History and Contemporary Development of the Vigilante. Journal of International Commercial Law and Technology, 7(1), 43-64.

Kiesler, S., Siegal, J. \& McGuire, T. (1984). Social Psychological Aspects of Computer-Mediated Communication. American Psychologist, 39(10), 113-1134. doi:10.1037/0003-

066X.39.10.1123 
Koetsier, J. (2013, March 21). Breaking: Adria Richards Fired by SendGrid for Calling Out Developers on Twitter. Venture Beat. Retrieved from http://venturebeat.com/2013/03/21/breaking-adria-richards-fired-by-sendgrid-for-outtingdevelopers-on-twitter/

Lanctôt, N., Cernkovich, S. A \& Giordano, P. C. (2007). Delinquent Behaviour, Official Delinquency and Gender: Consequences for Adulthood Functioning and Well-Being. Criminology, 45(1), 131-157. doi:10.1111/j.1745-9125.2007.00074.x

Mann, L. (1981). The Baiting Crowd in Episodes of Threatened Suicide. Journal of Personality and Social Psychology, 41(4), 703-709. doi:10.1037/0022-3514.41.4.703

Mathes, E. W. \& Guest, T. A. (1976). Anonymity and Group Antisocial Behaviour. The Journal of Social Psychology, 100(2), 257-262. doi:10.1080/00224545.1976.9711936

Mathes, E. W. \& Kahn, A. (1975). Diffusion of Responsibility and Extreme Behaviour. Journal of Personality and Social Psychology, 31(5), 881-886. doi:10.1037/h0076695

Millar, S. (2008, January 14). Facebook Groups Violate Publication Bans. Interrobang. Retrieved from http://www.fsu.ca/interrobang_article.php?storyID=2919\& sectionID=1\&issueID=73

Misener, D. (2013, November 19). YouTube's New Comments Policy Meant to Spark 'Conversations'. CBC News. Retrieved from http://www.cbc.ca/news/technology/youtubes-new-comments-policy-meant-to-spark-conversations-1.2431715

Moore, M., Nakano, T., Enomoto, A., \& Suda, T. (2012). Anonymity and Roles Associated with Aggressive Posts in an Online Forum. Computers in Human Behavior, 28(3), 861-867. doi:10.1016/j.chb.2011.12.005

Neapolitan, J. (1987). Vigilante Behavior and Attribution Bias. Criminal Justice and Behavior, 14(2), 123-137. doi:10.1177/0093854887014002001

Ore, J. (2015, May 15). Reddit Targets Bullying, Sexism and Doxing With New Anti-Harassment Policy. $C B C$ News. Retrieved from http://www.cbc.ca/news/trending/reddit-targetsbullying-sexism-and-doxing-with-new-anti-harassment-policy-1.3075928

Page, R. A. \& Moss, M. K. (1976). Environmental Influences on Aggression: The Effects of Darkness and Proximity of Victim. Journal of Applied Social Psychology 6(2), 126-133. doi:10.1111/j.1559-1816.1976.tb01318.x

Pallanik, K. (2008, January 5). Angry Facebook Users Illegally Leaked the Names of Accused Underage Murderers. Digital Journal. Retrieved from http://digitaljournal.com/article/248379

Powell, B. \& Mitchell, B. (2008). Gag Orders in a Facebook Age. The Toronto Star. Retrieved from http://www.thestar.com/news/gta/2008/01/04/gag orders in a facebook age.html 
Robinson, M., Kane, L., Duggan, E., \& Law, S. (2011, June 17). Vancouverites Fight Back Against Rioters Through Social Media. Vancouver Sun. Retrieved from http://www.vancouversun.com/news/Vancouverites+fight+back+against+rioters+through+ $\underline{\text { social+media/4958109/story.html }}$

Ronson, J. (2015, February 12). How One Stupid Tweet Blew Up Justine Sacco's Life. The New York Times Magazine. Retrieved from http://www.nytimes.com/2015/02/15/magazine/how-one-stupid-tweet-ruined-justine$\underline{\text { saccos-life.html }}$

Ryan, D. (2012, June 11). Rioting Teen Nathan Kotylak and Family Face Backlash, Forced to Leave Home. Vancouver Sun. Retrieved from http://www.vancouversun.com/technology/Rioting+teen+Nathan+Kotylak+family+face+b acklash+forced+leave+home/4972283/story.html

Santana, D. (2014). Virtuous or Vitriolic: The Effect of Anonymity on Civility in Online Newspaper Reader Comment Boards. Journalism Practice, 8(1), 18-33. doi:10.1080/17512786.2013.813194

Schneider, C. \& Trottier, D. (2012). The 2011 Vancouver Riot and the Role of Facebook in Crowd Sourced Policing. BC Studies, 175(Autumn 2012), 93-109.

Schneider, C. \& Trottier, D. (2013). Social Media and the 2011 Vancouver Riot. Studies in Symbolic Interaction, 40, 335-362. doi:10.1108/S0163-2396(2013)0000040018

Shanoff, A. (2011, February 6). Youth Criminal Justice Act Is Absurdly Secretive. Toronto Sun. Retrieved from http://www.torontosun.com/comment/columnists/ alan_shanoff/2011/02/04/17157946.html

Suler, J. (2004). The Online Disinhibition Effect. CyberPsychology and Behavior, 7(3), 321-326. doi:10.1089/1094931041291295

Tan, K. (2008, May 22). Online Lynch Mobs Find Second Post-Quake Target; Liaoning Girl Detained by the Police. The Shanghaiist. Retrieved from http://shanghaiist.com/2008/05/22/online_lynch_mo.php

Torrevillas, P. (2011, October 21). The Very Real Dangers of Naming and Shaming. Metro News. Retrieved from http://metronews.ca/news/vancouver/33028/the-very-real-dangers-ofnaming-and-shaming/

Trottier, D. (2012). Social Media as Surveillance: Rethinking Visibility in a Converging World. Farnham: Ashgate.

Vancouver Police Department, (2011). Vancouver Police Department 2011 Stanley Cup Riot Review. Retrieved from http://vancouver.ca/files/cov/2011-stanley-cup-riot-VPD.pdf 


\section{CGJSC / RCESSC}

Wehmhoener, K. A. (2010). Social Norm or Social Harm: An Exploratory Study of Internet Vigilantism. (Master's thesis). Retrieved from http://lib.dr.iastate.edu

Wright, M. F. (2013). The Relationship Between Young Adults' Beliefs About Anonymity and Subsequent Cyber Aggression. Cyberpsychology, Behavior, and Social Networking, 16(12), 858-862. doi:10.1089/cyber.2013.0009

Wright, M. F. (2014). Predictors of Anonymous Cyber Aggression: The Role of Adolescents' Beliefs About Anonymity, Aggression, and the Permanency of Electronic Content. Cyberpsychology, Behavior, and Social Networking, 17(4), 431-438. doi:10.1089/cyber.2013.0457

Zimmerman, A. G., \& Ybarra, G. J. (2014, June 16). Online Aggression: The Influences of Anonymity and Social Modeling. Psychology of Popular Media Culture. Advance online publication. doi:10.1037/ppm0000038

Legislation

Criminal Code (R.S., 1985, c. C-46)

Youth Criminal Justice Act (2002, c. 1) 